\title{
GC/GC-MS Analysis, Isolation and Identification of Bark Essential Oil Components from Cinnamomum culilawan, Blume
}

\author{
Hanoch Julianus Sohilait ${ }^{1}$, Healthy Kainama ${ }^{2}$ \\ ${ }^{1}$ Departement of Chemistry, Faculty of Mathematic and Natural Science, Pattimura University, Ambon, Indonesia \\ ${ }^{2}$ Departement of Chemistry Education, Faculty of Training and Education, Pattimura University, Ambon, Indonesia \\ Email address: \\ nokesohilait@yahoo.com (H. J. Sohilait)
}

\section{To cite this article:}

Hanoch Julianus Sohilait, Healthy Kainama. GC/GC-MS Analysis, Isolation and Identification of Bark Essential Oil Components from Cinnamomum culilawan, Blume. American Journal of Applied Chemistry. Vol. 4, No. 4, 2016, pp. 157-160.

doi: $10.11648 /$ j.ajac.20160404.16

Received: July 1, 2016; Accepted: July 13, 2016; Published: August 2, 2016

\begin{abstract}
The essentials oils (EO) in Cinnamomum culilawan bark have been isolated by steam distillation and evaluated by GC/GC-MS, IR and NMR methods. The GC/GC-MS analysis identified 12 compounds. The major components are eugenol $(66.477 \%)$, safrole $(12.432 \%)$ and methyleugenol (6.972\%). Repeated purification of the two main compounds yielded eugenol $(51.66 \%)$, and safrole $(6.71 \%)$.
\end{abstract}

Keywords: Cinnamomum culilawan, Bark Essential Oil, Chemical Composition, Eugenol, Safrole

\section{Introduction}

The lawang tree, Cinnamomum culilawan (Lauraceae), grows naturally in Moluccas Islands, and west Papua, East Indonesia [1, 2]. The local name of this tree in Moluccas Islands is lawang; the trunk of tree can grow as high as 1220 meters, on altitudes of $300 \mathrm{~m}$ above sea level. The culilawan oil is produced through steam distillation of the tree bark and the oil of culilawan is usually used as a pain killer for aches and pains in Moluccas Islands. Also, the lawang bark extract is used for tradisional medicine such as tooth aches, muscular pains and stomach aches in Papua [3]. While many plants from some genera have been studied and some even commercially explored for essential oils, some of those are Cinnamomum sintoc [4, 5], Cinnamomum carolinense [6] and Cinnamomum bodinieri [7], the species Cinnamomum culilawan has been rarely investigated. Isolation of safrole from culilawan oil from other places in West Seram, Moluccas and Papua has been reported [8, 9], but the chemical constituent of this oil not presented in those papers yet.

This paper reports results of chemical composition of culilawan oil obtained from original trees grown in Ambon Island.

\section{Materials and Methods}

\subsection{Materials}

The barks of lawang three were collected from Allang Village, Ambon Island, Moluccas in January 2016 and were deposited in the Organic Chemistry Laboratory, Pattimura University, Ambon. The raw material was air-dried until constant weight and chopped into small pieces.

\subsection{Chemicals and Equipment}

The chemicals in the study are: sodium hydoxide p.a (E. Merck), petrolium ether $35-60^{\circ} \mathrm{C}$ p.a (J. T. Baker), anhydrous sodium sulfate p.a (E. Merck), sodium chloride p.a (E. Merck), hydrochloric acid $30 \%$ p.a (E. Merck). The tools used in this study are, a set of fractional distillation under reduced pressure, electric heaters, evaporators and tools Buchi laboratory glassware, Gas Chromatography GC-2010, Shimadzu, an Infra Red spectrophotometer (FTIR-8400S, Shimadzu), ${ }^{1}$ H-NMR, Spectrophotometer (JEOL-MY 400, MHz), ${ }^{13} \mathrm{C}-\mathrm{NMR}$, Spectrophotometer (JEOL-MY 100, MHz), MassSpectrophotometer (GC-MS QP-2010 Plus, Shimadzu). 


\subsection{Isolation of Essential Oil from Bark of Cinnamomum culilawan, $B l$}

The dry plant material $(2.0 \mathrm{~kg})$ from bark of Cinnamomum culilawan was steam-distilled using conventional steam distiller for 6 hours to obtain the essential oil. The essential oil were then dried by anhydrous sodium sulfate $\left(\mathrm{Na}_{2} \mathrm{SO}_{4}\right)$ and cool-stored in brown bottle for further analysis.

\subsection{Gas Chromatography (GC) Analysis}

GC analysis of the culilawan oil was performed on a Shimadzu QP-2010, equipped with a FID and Rtx-5 using a fused silica capillary column $(30 \mathrm{~m} \times 0.25 \mathrm{~mm}$ ID, film thickness $1.0 \mu \mathrm{m})$. Oven temperature was from $60^{\circ} \mathrm{C}$ for 5 minutes and programmed heating from 60 to $180^{\circ} \mathrm{C}$ at a rate of $20^{\circ} \mathrm{C}$ for 5 minutes, and from $280^{\circ} \mathrm{C}$ for 4 minutes, injector temperature $270^{\circ} \mathrm{C}$, detector temperature $280^{\circ} \mathrm{C}$, pressure of carrier nitrogen gas at inlet 7 psi, split 20 and volume was $0.5 \mu \mathrm{L}$.

\subsection{Gas Chromatography-Mass Spectrometry (GC-MS)}

GC-MS analyses of bark culilawan oil were performed using Shimadzu QP-2010 Plus at $70 \mathrm{eV}$ and $320^{\circ} \mathrm{C}$ with auto sampler, system equipped with Rtx-5 fused silica capillary column (30 m x $0.25 \mathrm{~mm}$ ID, film thickness $1.0 \mu \mathrm{m})$. Oven temperature was from $60^{\circ} \mathrm{C}$ for 5 minutes, then programmed heating from 60 to $220^{\circ} \mathrm{C}$ at a rate of $10^{\circ} \mathrm{C}$ for 5 minutes, and from $280^{\circ} \mathrm{C}$ for $4 \mathrm{~min}$, injector temperature $270^{\circ} \mathrm{C}$. The carrier gas was helium at flow rate of $1.40 \mathrm{~mL} / \mathrm{min}$. Spectra were scanned from 40 to $600 \mathrm{~m} / z$, split ratio 20 , ion source temperature $225^{\circ} \mathrm{C}$. The spectrum of the unknown component was compared with that of known components stored in the Wiley 7 library. Name, molecular weight and structure of the component of the test materials were ascertained.

\subsection{Isolation of Two Main Components from Cullilawan Oil}

In a $500 \mathrm{~mL}$ flask, $\mathrm{NaOH}(20.0 \mathrm{~g})$, aquades $(150 \mathrm{~mL})$ and culilawan oil (100.0 g) were chargedand the mixture were strired until forming two layers. The upper layer (A) was separated from the bottom layer (B). The upper layer was extracted with $25 \mathrm{~mL} \mathrm{NaOH} 20 \%$ and aquous layer was combined to bottom layer (B). The organic layer (A) was washed with water until neutral and dried with $\mathrm{Na}_{2} \mathrm{SO}_{4}$ anhydrous and the residue was distilled under reduced pressure at $15 \mathrm{mmHg} / 120^{\circ} \mathrm{C}$. The bottom layer (B) was acidified with $\mathrm{HCl} 20 \%$ until $\mathrm{pH}$ reached 3 and extracted twice with $100 \mathrm{~mL}$ petroleum eter. The organic layer was washed until neutral and dried over anhydrous $\mathrm{Na}_{2} \mathrm{SO}_{4}$. After removing the petroleum ether, the residue was distilled under reduced pressure at $15 \mathrm{mmHg} / 140^{\circ} \mathrm{C}$. The purity of compounds was tested by $\mathrm{GC}$ and the elucidation of the structures employed FTIR, ${ }^{1} \mathrm{H}-\mathrm{NMR},{ }^{13} \mathrm{C}-\mathrm{NMR}$ and GC-MS methods.

\section{Results and Discussion}

\subsection{Performance of Bark Essential Oil of Cinnamomun culilawan, $B l$.}

The bark essential oils of $C$. culilawan was distilled from dry plant material on equipment of the steam distillation. Culilawan oil obtained from steam-distillation revealed that oil from the bark have a yield of $4.12 \% \mathrm{w} / \mathrm{w}$.

\subsection{Chemical Composition of Bark Essential Oil of Cinnamomun culilawan}

Table 1. Chemical composition of bark essential oils of Cinnamomun culilawan, Bl.

\begin{tabular}{llllllll}
\hline Peak No. & Retention time (min) & Compoud Name & M. W & Formula & Conc(\%) & Base peaks & Main Fragment ion (m/z) \\
\hline 1 & 5.919 & $\alpha$-thujene & 136 & $\mathrm{C}_{10} \mathrm{H}_{16}$ & 0.516 & 93 & $41,65,77,93,136$ \\
2 & 6.083 & $\alpha$-pinene & 136 & $\mathrm{C}_{10} \mathrm{H}_{16}$ & 1.999 & 93 & $41,67,93,121,136$ \\
3 & 6.942 & $\beta$-pinene & 136 & $\mathrm{C}_{10} \mathrm{H}_{16}$ & 0.631 & 93 & $41,69,79,93,121,136$ \\
4 & 7.733 & o-cymene & 134 & $\mathrm{C}_{10} \mathrm{H}_{14}$ & 1.590 & 119 & $65,77,91,119,134$ \\
5 & 7.800 & Limonena & 136 & $\mathrm{C}_{10} \mathrm{H}_{16}$ & 0.856 & 93 & $41,53,68,79,93,107,121,136$ \\
6 & 7.850 & 1,8 -cineol & 154 & $\mathrm{C}_{10} \mathrm{H}_{18} \mathrm{O}$ & 2.431 & 43 & $41,43,69,81,84,108,139,154$ \\
7 & 8.758 & Linalool & 154 & $\mathrm{C}_{10} \mathrm{H}_{18} \mathrm{O}$ & 4.852 & 71 & $41,43,69,71,93,121,136$ \\
8 & 9.700 & 4-terpineol & 154 & $\mathrm{C}_{10} \mathrm{H}_{18} \mathrm{O}$ & 0.651 & 71 & $41,43,71,93,111,154$ \\
9 & 10.775 & Safrole & 162 & $\mathrm{C}_{10} \mathrm{H}_{10} \mathrm{O}_{2}$ & 12.432 & 162 & $51,77,104,131,162$ \\
10 & 11.450 & Eugenol & 164 & $\mathrm{C}_{10} \mathrm{H}_{12} \mathrm{O}_{2}$ & 66.477 & 164 & $55,77,91,103,131,149,164$ \\
11 & 11.700 & Methyleugenol & 178 & $\mathrm{C}_{11} \mathrm{H}_{14} \mathrm{O}_{2}$ & 6.972 & 178 & $41,65,77,91,107,135,147,163,178$ \\
12 & 12.908 & Myristicin & 192 & $\mathrm{C}_{11} \mathrm{H}_{12} \mathrm{O}_{3}$ & 0.592 & 192 & $65,77,91,119,131,147,161,192$ \\
\hline
\end{tabular}

a) Concentration of compounds base on GC-FIDpeaks (see Figure 1) and the isolated of compounds were highlighted in bold face.

b) Identified by FTIR, ${ }^{1} \mathrm{H}-\mathrm{NMR},{ }^{13} \mathrm{C}-\mathrm{NMR}$ and $\mathrm{MS}$

The essential oil, Bl was analyzed by GC and GC-MS. Twelve components were identified and quantified, as shown in Table 1, according to their elution order on the Rtx-5 column. The major components are safrole (12.432\%), eugenol $(66.477 \%)$ and methyleugenol $(6.972 \%)$, (Figure 1, Table 1).
The minor constituents of the oil included the monoterpenes hydrocarbon $(5.592 \%)$, oxygenated monoterpenes $(7.934 \%)$. Between the minor constituents of the oil, the oxygenated monoterpenes linalool $(4.852 \%)$ and 1,8-cineol $(2.431 \%)$ were the most representatives, totaling other $7.283 \%$ of the oil. The phenylpropanoid compounds 
$(86.473 \%)$ with myristicin did at low concentration $(0.592 \%)$.

Due to very limited amount of published data on Cinnamomun culilawan, Bl essential oil, it is difficult to compare results of this study with essential oil composition of plant grown in other countries.

\subsection{Isolation of Two Main Components from Culilawan Oil}

The percent contents of the EO were determined on the basis of their FID responses upon GC (Figure 1). Eugenol (1) was the major component $(66.477 \%)$ of the EO (Figure 1, Table 1) followed by Safrole (12.432\%), and methyleugenol $(6.972 \%)$.

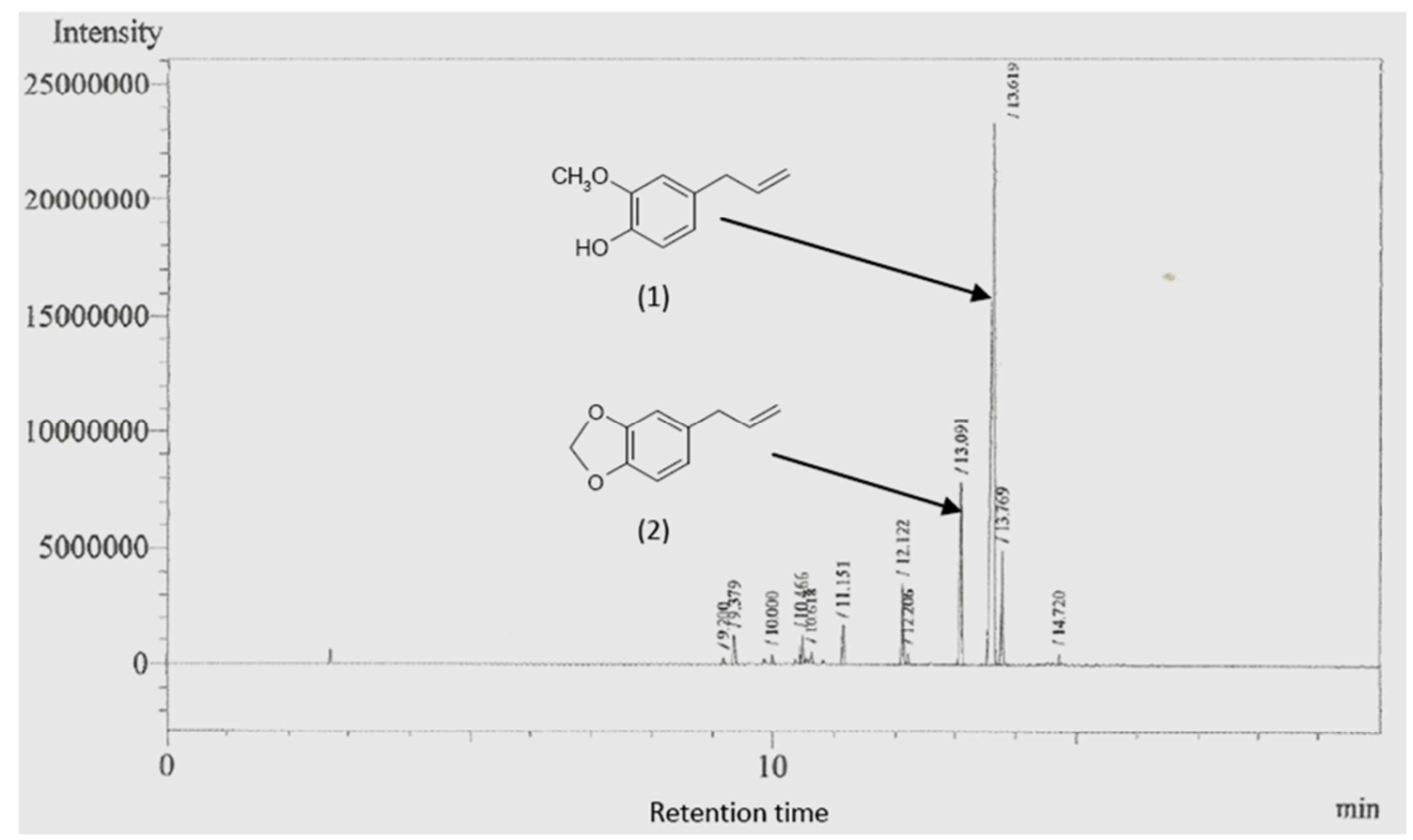

Figure 1. GC-FID peaks for\% oil and the structure for isolated compounds (1 and 2) from the bark essential oil of Cinnamomun culilawan.

The isolation of eugenol (1) from culilawan oil is effected by using sodium hydroxide solution to obtain sodium eugenolate followed by regeneration with $20 \%$ hydrochloric acid. The mixture was extracted with petroleum ether and the solution was washed with water until neutral and dried over anhydrous $\mathrm{Na}_{2} \mathrm{SO}_{4}$. After removing the petroleum ether, the residue was distilled under reduced pressure at 15 $\mathrm{mmHg} / 140^{\circ} \mathrm{C}$ yield $(51.66 \%)$. Spectrum IR $\left(\mathrm{cm}^{-1}\right)$ : 3475, 2976, 2842, 1638, 1613, 1432, 1149, 1034. Spectrum ${ }^{1} \mathrm{H}-$ NMR (400 MHz, $\left.\mathrm{CDCl}_{3}, \mathrm{ppm}\right), \partial: 3.41\left(d-\mathrm{CH}_{2-}, J=6.8\right.$ $\mathrm{Hz}), 3.86\left(\mathrm{~s}-\mathrm{OCH}_{3}\right), 5.16\left(\mathrm{~d},=\mathrm{CH}_{2}\right), 5.20(\mathrm{~s},-\mathrm{OH}), 6.05(\mathrm{~m}$, $-\mathrm{CH}=, J=6.8 \mathrm{~Hz}$ ), 6.76 (s, H, C3Ar), 6.78 (d, H, C6Ar), 6.98 (d, H5-Ar). ${ }^{13} \mathrm{C}-\mathrm{NMR}(100 \mathrm{MHz}, \mathrm{CDCl} 3)$ 2: $40.01\left(-\mathrm{CH}_{2}-\right)$, $55.95\left(-\mathrm{OCH}_{3}\right), 111.20\left(=\mathrm{CH}_{2}\right), 114,37(\mathrm{C} 2-\mathrm{Ar}), 115.65(\mathrm{C} 5-$ Ar), 121.26 (C6-Ar), 132.03 (C1-Ar), 137.95 (-CH=), 143.95 (C4-Ar), 146.53 (C3-Ar). The spectral data matched that given in a previous report [10]. The Infra-red spectrum of eugenol (1) showed absorption band in the $3475 \mathrm{~cm}^{-1}(-\mathrm{OH})$, in the region $2976 \mathrm{~cm}^{-1}$ which is the absorption $\mathrm{Csp}^{3}-\mathrm{H}$, this was confirmed by the appearance of absorption at $1432 \mathrm{~cm}^{-1}$ for $-\mathrm{CH}_{2}-$ (methylene). The range of $\mathrm{C}=\mathrm{C}$ aliphatic absorption appeared at $1638 \mathrm{~cm}^{-1}$, absorption at $1613 \mathrm{~cm}^{-1}$ for $\mathrm{C}=\mathrm{C}$ aromatic and supported by absorption at $2976-2842 \mathrm{~cm}$ ${ }^{1}$ which is absorption band for $=\mathrm{Csp}^{2}-\mathrm{H}$ (aliphatic/aromatic). Absorption band at $1149 \mathrm{~cm}^{-1}$ and $1034 \mathrm{~cm}^{-1}$ region showed the range of $\mathrm{C}-\mathrm{O}-\mathrm{C}$ (ether). The ${ }^{1} \mathrm{H}-\mathrm{NMR}$ spectrum, signal doublet at $3.41 \mathrm{ppm}\left(-\mathrm{CH}_{2-}, J=6.8 \mathrm{~Hz}\right)$ and signal multiplet at $6.06 \mathrm{ppm}(-\mathrm{CH}=, J=6.8 \mathrm{~Hz})$, signal singlet at $3.86 \mathrm{ppm}$ of one methoxy group. The ${ }^{13} \mathrm{C}$-NMR spectrum showed 10 nonequivalent carbon resonances and the MS spectrum showed a molecular ion peak $\left[\mathrm{M}+\right.$.] at $m / z$ 164, $\mathrm{C}_{10} \mathrm{H}_{12} \mathrm{O}_{2}$ (see table 1).

The upper layer containing safrole (2) was processed as follows; the solution was washed with water until neutral followed by drying over anhydrous $\mathrm{Na}_{2} \mathrm{SO}_{4}$. After removing petroleum ether, the residue was distilled under reduced pressure $15 \mathrm{mmHg} / 120^{\circ} \mathrm{Cyield}(6.71 \%)$. Spectrum IR $\left(\mathrm{cm}^{-1}\right)$ : 2977, 2842, 1639, 1608, 1432, 1246, 1034. Spectrum ${ }^{1} \mathrm{H}-$ NMR (400 MHz, $\left.\mathrm{CDCl}_{3}, \mathrm{ppm}\right), \partial: 3.33\left(d-\mathrm{CH}_{2^{-}}, J=6.4 \mathrm{~Hz}\right)$, $5.10\left(\mathrm{~m},=\mathrm{CH}_{2}\right), 5.95\left(\mathrm{~s},-\mathrm{OCH}_{2} \mathrm{O}-\right), 6.00(\mathrm{~m},-\mathrm{CH}=, J=6.4$ Hz), 6.67 (d, H-C5Ar), 6.74 (s, C3-Ar), 6.84 (d, H-C6-Ar. ${ }^{13} \mathrm{CNMR}(100 \mathrm{MHz}, \mathrm{CDCl} 3)$ : $\partial: 40.06\left(-\mathrm{CH}_{2}-\right), 100.95$ ($\left.\mathrm{OCH}_{2} \mathrm{O}-\right), 108.30$ (C3-Ar), 109.23 (C5-Ar), $115.82\left(=\mathrm{CH}_{2}\right)$, 121.44 (C6-Ar), 133.96 (C1-Ar), 137.80 (-CH=), 145.99 (C4-Ar), 147.90 (C3-Ar). The spectral data matched that given in a previous report $[11,12]$.

The Infra red spectrum of safrole (2) showed absorption band in the region $2977 \mathrm{~cm}^{-1}$ which is the absorption Csp3-H. This was confirmed by the appearance of absorption at 1432 $\mathrm{cm}^{-1}$ for $-\mathrm{CH}_{2^{-}}$(methylene). Untake range of $\mathrm{C}=\mathrm{C}$ aliphatic absorption appeared at $1639 \mathrm{~cm}^{-1}$, absorption at $1608 \mathrm{~cm}^{-1}$ for $\mathrm{C}=\mathrm{C}$ aromatic and supported by absorption at $2977-2842 \mathrm{~cm}^{-}$ ${ }^{1}$ which is absorption band for $=\mathrm{Csp}^{2}-\mathrm{H}$ (aliphatic/aromatic). Absorption band at $1246 \mathrm{~cm}^{-1}$ and $1034 \mathrm{~cm}^{-1}$ region showed 
the range of C-O-C (ether). The ${ }^{1} \mathrm{H}-\mathrm{NMR}$ spectrum, signal doublet at $3.33 \mathrm{ppm}\left(-\mathrm{CH}_{2^{-}}, J=6.4 \mathrm{~Hz}\right)$ and signal multiplet at $6.00 \mathrm{ppm}(-\mathrm{CH}=, J=6.4 \mathrm{~Hz})$, signal singlet at $5.95 \mathrm{ppm}$ of one methylenedioxy group. The ${ }^{13} \mathrm{C}$-NMR spectrum showed 10 nonequivalent carbon resonances and the MS spectrum showed a molecular ion peak [M+.] at $m / z 162, \mathrm{C}_{10} \mathrm{H}_{10} \mathrm{O}_{2}$ (see table 1). The high concentration of eugenol in bark essential oil of Cinnamomun culilawan makes it potentially useful for the preparation of herbal and modern medicines because they exhibit antibacterial, antifungal, antiinflammatory, insecticidal and antioxidant activities [11-15].

\section{Conclusions}

The chemical composition of essential oil from Cinnamomun culilawan, B1, was obtained from steam distillation method, and its chemical composition was determined by GC and GC-MS. The result indicated that the essential oil is mainly phenylpropanoid compound $(86.473 \%)$, the minor compounds are oxygenated monoterpenes $(7.934 \%)$ and monoterpenes hydrocarbon $(5.592 \%)$. The purification of the two main compounds yielded eugenol (51.66\%), and safrole (6.71\%).

\section{Acknowledgement}

This study is part of the Fundamental Research Grant in 2015 from the Director General of Reasearch and Community Service, Ministry of Research, Technology and Higher Education, Indonesia.

\section{References}

[1] Ketaren S, Pengantar Minyak Atsiri, PN. Balai Pustaka, Jakarta, 1985

[2] Sastrohamidjojo H, Kimia Minyak Atsiri, Gadjah Mada University Press, 2004.

[3] LenseO, The wild plants used as traditional medicines by indigenous people of Manokwari, West Papua, Bio Diversitas, 2012, 13 (2), 98-106.

[4] Jantan I, Ali N. A. M, Ahmad A. R and Ahmad A. S, Chemical constituents of the essential oils of Cinnamomum sintoc, Blume, Pertanika J. Sci. \& Techno., 1994, 2 (1), 39-45.
[5] Iskandar Y, Supriyatna S, Chemical composition of volatile oil from Cinnamomum sintoc stem barks, Proceeding of The international seminar on chemistry, Jatinangor, Indonesia, 2008, 601-603

[6] Reynertson K. A, Balick M. J, Lee R, Raynor W, Pelep Y, Kennelly E. J, A traditional method of Cinnamomum carolinense preparation eliminates safrole from a therapeutic Pohnpean tea, J. Ethnopharmacology, 2005, 102, 269-274.

[7] Luo Y, LuoYo, Chen F, Liu H, Studies on the Chemical constituents in the essential oils from the leaves of Cinnamomum bodinieri Levi, Adv. Meterials Res., 2014, 1015, 373-376.

[8] Kapelle I. B. D, Irawadi, T. T, Rusli M. S, Mangunwidjaja D, Mas'ud, Z. A, Synthesis of new curcumin analogues from kulitlawang oils using the conventional method and microwave, Sci. J. Chem., 2015, 3 (3): 50-56.

[9] Sohilait M. R, Sohilait, H. J, Fransina E, 2013, Synthesis of 34-methylenedioxy isoamylcinamic as the sunscreen Compound from culilawang oil, Ind. J. Chem. Res., 2013, 1, $1-5$.

[10] Li H. Q, Liu Q. Z, Liu Z. L, Du Sh. Sh and Deng Z. W, Chemical composition and nematicidalactivity of essential oil of Agastacherugosaagainst Meloidogyne incognita, Molecules, 2013, 18, 4170-4180.

[11] Chu S. S, Cheng Fang Wang C. F, Du S. S, Liu S. L, Liu Z. L, Toxicity of the essential oil of Illiciumdifengpistem bark and its constituent compounds towards two grain storage insects, J. Insect Sci., 2011, 11 (152), 1-10.

[12] Valente V. M. M, Jham G. N, Jardim C. M, Dhingra O. D, Ghiviriga I, Major antifungals in nutmeg essential oil against Aspergillus flavus and A. ochraceus, J. Food Res., 2015, 4 (1), 51-57.

[13] Kamatou G. P, Vermaak I and Viljoen A. M, Eugenol- From the remote Maluku Islands to the international market place: A review of a remarkable and versatile molecule, Molecules, 2012, 17, 6953-6981.

[14] Huang Y, Ho S. H, Lee H. C, Yap Y. L. Insecticidal properties of eugenol, isoeugenol and methyleugenol and their effectson nutrition of Sitophilus zeamais Motsch. (Coleoptera: Curculionidae) and Tribolium castaneum (Herbst) (Coleoptera: Tenebrionidae), J. Stored Prod. Res., 2002, 38, 403-412.

[15] Ozturk A, Ozbek H, The Anti-inflammatory activity of Eugenia caryophyllata essential oil: An animal model of antiinflammatory activity, Eur. J. Gen. Med., 2005, 2 (4), 159163. 